\title{
The Coalition against the "War on Terror" in Light of International Politics, Law, and Protecting Human Welfare
}

\section{Kaleem Hussain}

In the universal realms of international law, all the associated political, social, legal, and religious actors would seek to strive to live in a world where there is justice, peace, tolerance, enhancement of human welfare, and friendly relations between states. ${ }^{1}$ Unfortunately, these universal ideals are far from being achieved or adhered to in our contemporary international society. The horrific attacks on the World Trade Center and the Pentagon, which provided the catalyst for the global "war on terror" starting in Afghanistan, raises numerous questions in international law and the global political realm. In all of its forms, terrorism is a disease that breeds fear and leads to the devastation and destruction of human lives, societies, and nations. It is also a topic that many historians and legalists try to avoid, at times, due to its promiscuity and subversive nature.

In this short article, I argue that terrorism is not a new phenomenon as such, but that it has been part of international society throughout the ages. However, since 9/11, it has experienced a sporadic injection and revitalization that has raised it from a nationalistic, racial, religious, or ideological phenomenon to one that has appeared on the global agenda with a symbolic significance. I question the motifs of the "war on terror," due to its relative unpredictability, on definitional grounds. Additionally, I challenge whether this is leading to an all-inclusive society based on uplifting human welfare, or whether it is creating a global discord of division, tension, antagonism, and resistance that may filter through the politics of the inter- and intrastate system and thus create tragedy, conflict, and destruction of global proportions.

Kaleem Hussain has an LLB Law and an LLM in international economic law from Warwick University, the United Kingdom. His interests are law, politics, economics, sociology, and classical and contemporary Islamic affairs. Currently, he is pursuing his LPC at the College of Law, Birmingham, the United Kingdom. 


\section{The Historical Evolution of Terrorism in International Society}

In light of the coalitions on the "war on terror" that have transpired since 9/11, the historical evolution of international society and world history shows that groups, nations, and states have been fighting terror for a long time but in a different context. We can say that its origin can be found in the French revolution of 1789 as propounded by Maximilien de Robespierre (d. 1794): the "système, régime de la terreur." Many of these "wars" and coalitions have been fought on political, ideological, and religious grounds. Karl Marx (d. 1883) and Friedrich Engels (d. 1895), both of whom endorsed the viewpoint that violence was a means of social change, were predominantly against the social order of their times and advocated revolutionary rhetoric to transform societies. ${ }^{3}$

History shows that coalitions have fought many systematic orders, from fascism under Adolf Hitler (d. 1945) to communism under Josseph Stalin (d. 1953), and many would now state that we are seeing a disproportionate regime developing between the capitalistic states and the backlash from the developing countries. This apparent dichotomy in transnational border disputes questions the evolution of an inclusive international society when the social, economic, and political gaps between the developed and the developing states are so vast. In many respects, however, coalitions have become part of the international norm triggered by such seismic events such as the First World War, the Second World War; the 1980s-90s in the coalition against Iraq, Nicaragua, and Somalia; and now the "war on terror" with the attack on the World Trade Center and the Pentagon. This shift from the national domestic realm to the global political realm raises many issues. But to undertake this shift of global significance, there has to be a unified objective or ideal uniting these states from the politics of the interstate system to the politics of the intrastate system in international law and society.

\section{The "War on Terror" and International Issues of State Centrism}

In terms of the coalition against terror, such academics as Adam Roberts argue that the laws of war and arms control should also apply to this antiterror war. ${ }^{4}$ Other academics, among them Phyllis Bennis, question whether the attack on Afghanistan is a war in the conventional form, as we know it. ${ }^{5}$ She states that the language of war used by American leaders, such as "you are with us or against us," "a new kind of war," or "we want him dead or 
alive," encapsulates war-like rhetoric in the minds of the masses to create civil discord and tensions around the world.

In terms of international law, 9/11 and the American response pose numerous questions as to the validity and justification of American reprisals in Afghanistan, Iraq, and elsewhere in the world. Chapter 7 of the United Nation's charter covers the "Use of Force." The United States could have used Article 52 and had the Security Council authorize its attack on Afghanistan. Alternatively, the more viable option was for the United States, the "victim state," to invoke the right to individual and collective self-defense under Article 51 (responding to an attack against a UN member state). Equally, the United States agreed that this incident was covered by Article 5 of the Washington Treaty, which states that an "armed attack" against one or more of the allies in Europe or North America shall be considered an attack against them all." ${ }^{\prime \prime}$ Thus, this justified the North Atlantic Treaty Organization's (NATO) joining with the United States to assist the attacked state with its armed reprisal based on self-defense.

However, this should only apply if the attack comes from abroad, and the use of force has to be roughly proportionate to that of the attacked state. Many are still not convinced as to who is responsible for $9 / 11$. We were led to believe that is was Osama bin Laden and his al-Qaeda network, and since he or his network were based in Afghanistan, this initially justified the coalition's counter-terrorist response against Afghanistan. ${ }^{8}$ One has to question the scope of this self-defense mechanism, as many would argue that Article 51 is for emergency responses, while the coalition against Afghanistan took three weeks to assemble before attacking. In terms of proportionality, the initial target was Bin Laden and his network; however, thousands of innocent civilians have been the major victims of the American-led coalition attack against a nation that has no defense mechanism. ${ }^{9}$ In Kabul, "village women were tied up by the Americans and hair samples taken for DNA analysis to try to establish links with Osama bin Laden."'10

Thousands of innocent civilians have lost their lives since these armed reprisals. The CIA has been giving out as compensation $\$ 1,000$ to bereaved relatives, which indicates that something has gone catastrophically wrong. This has been classified as collateral damage, the notion that Donald Rumsfeld stated when addressing the media at home: It is inevitable that "innocent lives will be lost." Marc Herold estimates that 9/11 took 4,000 lives. ${ }^{11}$ In 2002, American bombs killed 1,300 civilians. At least 3,000 Afghans have died as a result of the American campaign, which was supposed to be diplomatic, humanitarian, and strategically targeted. 
This brings one back to the issue of proportionality. One questions whether this coalition on the "war on terror," the initial premise of which was based on "infinite justice" or now "enduring freedom," is creating a society based on the universal protection and enhancement of human welfare, since many innocent lives of a greater magnitude than $9 / 11$ have been lost. One asks if we are seeing the global coalition against terror, where states have set aside national sovereignty issues and cooperated with the United States in the "war on terror" not on the grounds of advancing human welfare, but due to their own vested economic, social, and political interests; where circumstances have dictated that they be "with the coalition" and "not against it," because the repercussions of their decision on a national state-centric level are too great for them not to be a part of this international campaign conducted by a few major states.

\section{Jurisdictional Issues in International Law on the "War on Terror"}

In terms of jurisdictional applicability, strenuous attempts have been made to reach a universal definition of terrorism in international law. ${ }^{12}$ Noam Chomsky defines terrorism as "the calculated use of violence or threat of violence to attain goals that are political, religious, or ideological in nature. This is done through intimidation, coercion, or instilling fear."'13 Although this is relevant for academic discourse, defining terrorism on a international scale has created more problems.${ }^{14}$ For example, many international conventions dealing with offences related to civil aviation and hijacking airplanes apply both to principals and accomplices. ${ }^{15}$ But in terms of their relevance for an all-inclusive recognition, many states are not signatories to it and there are limited sanctions for non-enforcement.

The language of "terrorism" has been brandished toward Libya, Syria, Iraq, Iran, Sudan, and Middle Eastern states in the main. However, the retrospective response from many of them is that the United States and its allies' foreign policy are the real embodiment of international "terrorism." This effectively creates an ideological desynchronization of state and intrastate interests by dividing countries into various groups and camps, which may lead to a new phenomena: "the clash of terrorists" in international society.

Article 2 (4) of the UN charter outlaws war, as it calls on all members to refrain from the threat or use of force against the political independence of any state in a manner inconsistent with the UN's purpose. The probable justification for intervention is if there is a threat to international peace or the 
need to overthrow a repressive or tyrannical regime. Interstate jurisdictional issues are further complicated by the principle of self-determination laid down in the charter's Article 1 (2). Until the recent "war on terror," these legal mechanisms provided the international checks and balances on global intervention that diminished any potential shift to the evolution of an inclusive international society as "one state's terrorist is another's national liberation movement." ${ }^{\prime 16}$ This legal juxtaposition prevented states from taking that shift or step further until 9/11. But what we are seeing now, according to Antonio Cassese, is the evolution of new customary international norms that transcend state structuralism and pay little regard to previous precedents, and thereby illegitimately legitimizing the use of force by a group of states (like the present coalition); in other words, the notion that in "international law [one should] allow the use of forcible countermeasures to impede the state from committing large-scale atrocities on its own territory, in circumstances where the Security Council is incapable of responding adequately to the crisis." ${ }^{17}$

The evolution of an all-inclusive international society is apparent when one applies the principle of universal jurisdiction in international law. ${ }^{18}$ Terrorist activity can emanate from states, quasi-states, interstate activity, and now intrastate and non-state activity. According to Jordan Paust, this raises important jurisdictional issues, as "we could not be at 'war' with Bin Laden since he and his entourage are in no way representative or leaders of an 'insurgency' within the meaning of international law. He also is not a recognised leader of a 'nation,' 'belligerent,' or 'state."'19 However, Cassese identifies two modes of legal response(s) to terrorism on this delicate issue, based on peaceful and coercive resolutions, and justifies coercive responses according to certain inherent principles. ${ }^{20}$ In this regard, I agree with Frederic L. Kirgis' insight and his recommendation for establishing an International Criminal Court (ICC). He states "[that] even though the International Criminal Court was not functioning then, terrorist acts mounting to crimes against humanity (9/11) would be subject to prosecution in domestic criminal courts around the world." ${ }^{21}$

The 1949 Geneva Convention's "Common Article 3" refers to noninterstate armed conflict mainly within the territory of one state. John Cerone argues that there may be some validity for "legal dynamism" to bring nonstate actors within the state mechanism if they are acting in an indirect manner on instructions from persons or groups that form part of the state. ${ }^{22}$ This analysis could apply to situations like the recent Lebanese crisis and Hizbullah's response to Israeli attacks. Although Hizbullah's members do have seats in the Lebanese governmental apparatus, the international 
community in the main regarded Hizbullah as a non-state actor financed directly or indirectly by Iran and Syria to defend Lebanon. If Hizbullah's actions were being endorsed and financed by Lebanon, then there is a strong possibility that they would fall under this provision. However, the greater likelihood is that the majority of instructions for Hizbullah's responses were coming from actors that did not form part of Lebanon, although the group's spiritual leader resides there. This certainly reveals scenarios that international law needs to address in a stratified manner.

Cassese endorses Cerone's proposal that the "new world order" is seeing a greater harmony and inclusiveness among states and that a permanent ICC would be an appropriate setting to try people for war crimes. However, he stresses that this demands the good will of state cooperation, as the proposed ICC still vests primacy in national jurisdictions. This suggestion would have credence if the United States were a signature to the ICC, as, at present, its citizens cannot be tried there, whereas other countries' citizens could be. In terms of the coalition's "war on terror," one has to establish whether acts of terrorism constitute war crimes that go beyond the realms of state sovereignty and should be tried, based on intra-state cooperation, at an all-inclusive international setting like the ICC. ${ }^{23}$

\section{The Politics of the "War on Terror"}

In terms of the counterterrorist reprisals in the "war on terror," the lack of a definition or universally agreed-upon definition of terror has proved, at times, to be the catalyst for injecting a global "war on terror." The crucial political language that has triggered this cross-border transnational attack is "any state that helps or harbours terrorism" is on the coalition's potential hit list, which gradually relinquishes the evolutionary norms in international law. ${ }^{24}$ Terrorism is a major destabilizing force in international society, and a unilateral transnational cooperative response is needed to tackle it effectively. However, such apolitical language as President George W. Bush's "axis of evil" designation for Iran, Iraq, and North Korea does not help the "war on terror"; rather, it instigates interstate antagonism that could lead to potential interstate destruction of human society and welfare on a global scale in this sensitive nuclear age.

Equally, over-obtrusive domestic and international laws designed to counter potential terrorists need to draw a fine balance between preserving individual human rights rather than infringing upon them in the quest for public protection and safety on a domestic and international scale. ${ }^{25}$ The notion of preemptive strikes in international law is also a cause for concern. The 
American-led coalition against Iraq justified its attack on what now transpires to be the false premises that Saddam Hussein had weapons of mass destruction (WMDs) and posed a grave threat to such countries as the United Kingdom and the United States, based on his alleged links to al-Qaeda ${ }^{26}$ However, to attack a state or a non-state actor before it has carried out a potential terrorist act on what is, at times, superficial evidence is a very serious situation as regards protecting human welfare in our global civic society.

Although the intelligence authorities try their best to thwart any potential terrorist act, one has to be extremely careful with the preemptive strike approach, for this essentially allows one state to attack another state or a non-state actor based on the "war on terror" before those actors have committed a crime. This has the potential of being a "loose legal cannon?" establishing new precedents in domestic and international legal norms in cases of justifying attacks or actions that may, in essence, not be based on the "war on terror." The recent alleged plot to blow up several trans-Atlantic airplanes is an example to which this analysis could potentially apply. What it entails is that even if one has the inclination or intention to commit a potentially criminal act without having committed that act, the authorities could prosecute him/her/them on the premise that he/she/they may carry it out in the future. ${ }^{27}$

It is precisely this type of analysis or conflict that Samuel Huntington warned of in his now widely acclaimed "clash of civilization theory" and the "remaking of world order." ${ }^{28} \mathrm{He}$ touches on the issue of a world in sheer chaos and the appearance of failed states facilitating this image, leading to the break up of states on tribal, political, religious, and ethnic grounds. This is masterminded by mass criminal operations, sporadic population shifts in refugees, and the "proliferation of nuclear and other weapons of mass destruction; the spread of terrorism; the prevalence of massacres and ethnic cleansing. ${ }^{29}$ In terms of the shift and emergence of an all-inclusive international society, Huntington stresses that "the West is the only civilization which has substantial interests in every other civilization or region and has the ability to affect the politics, economics, and security of every other civilization in the region." ${ }^{30}$

The American policy document, written in 2000 and based on the "Project for the New American Century," highlights how the United States needs to engage in simultaneous conflicts or wars in many parts of the world to foster its global strategic, military, and economic interests. ${ }^{31}$ In a recent address, President Bush stated that the ideological war of the twenty-first century is based on promoting freedom and democracy against the terrorists and extremist aspects in global society at large. He also attempted to justify 
the wars in Afghanistan and Iraq by mentioning that who controls the world's oil resources is a vital issue for the twenty-first century. He did not want to see the United States compromise with Arab states and those lands that might become oil-rich in the future, due to newly discovered deposits, merely because they control the supply of oil and hence could dictate American policy decisions based on this inherited bargaining position. ${ }^{32}$ In other words, this all-inclusive international society unites not to protect and enhance human welfare on a global scale, but rather to enhance and preserve its political, economic, social, military, and strategic objectives in the universal intrastate global political system.

In terms of the "war on terrorism," this reality has now manifested itself on a global scale. Many states, creeds, cultures, religions, and ideologies claim that this "war" is being used as a pretext to interfere in the politics of interstate disputes and conflicts around the world, thereby creating the proverbial backlash. ${ }^{33}$ Historical struggles such as in Israel and Palestine, ${ }^{34}$ the Balkans, Central Asia, Iraq, Kashmir (India-Pakistan), Sudan, Rwanda, and elsewhere have been, or are in the process of being, subjected to some form of UN peacekeeping operations and, at times, sanctions. ${ }^{35}$ There are suggestions that the next American-led coalition target in the "war on terror" may be Iran, ${ }^{36}$ which may test the American-British special relationship. Referring to the coalition's possible future premeditated response under the universal umbrella of fighting a "war on terrorism," Huntington warned: "In the coming era, in short, the avoidance of major inter-civilizational wars requires core states to refrain from intervening in conflicts with other civilizations. ${ }^{137}$ Thus, he advocates that the major powers play a greater mediatory role.

\section{Concluding Remarks}

There is a unanimous opinion that $9 / 11$ was a rude awakening not just for the United States in terms of the attack, but for many states and supranational blocs around the world to reassess state, interstate, and what I would call "intrastate transnational security" to prevent similar horrific terrorist acts from occurring again. We have a more all-inclusive international community, rather than a society based on collective security principles and cooperation to eradicate terrorism. Numerous instant legal and documentary responses have taken place at a national and international level not only to define terrorism, but also to provide a concerted framework for responses from the European Union, the United States, the Russian Federation, Asia, and Arab and Muslim countries, all of which share the common ideal of eradicating terrorism. ${ }^{38}$ 
Contemporary terrorists are highly sophisticated actors who utilize the development and advancements of modern technology, armaments (nuclear), biological weapons, media, and mass communications via the Internet in this global age. Many people feel that there is no emphatic difference between cyber war and conventional warfare, and they both demand equal attention. ${ }^{39}$ Thus, all states need to reassess security measures on both the state and on the inter-intra state levels to deal with modern "terrorists," is a sophisticated bug that requires a multi-dimensional, anti-virus, counterterrorist, holistic response in coordination with various groups, state organs, states, and intelligence departments on a multilateral basis. ${ }^{41}$

Clearly, promoting the enhancement of human welfare and eradicating terrorism demands that all players, be they in the form of a coalition or not, act in concert to achieve this aim. However, the language of "war" and "terror" used by certain officials in authority is creating a destabilizing situation that may have a catastrophic significance for humanity's overall welfare. Only if states and civilizations act in harmony and tackle the root causes of terrorism, rather than having reactionary enforcement responses toward each other, can the potential "clash of civilizations" be renounced and lead to the peaceful coexistence of civilizations based on principles of justice and enhancing such universal norms as humanity's overall welfare.

\section{Endnotes}

1. Art 2 (3) \& Art 2 (4) of the United Nations Charter 1945. See also 1970 declaration on "Principles of International law concerning Friendly Relations \& Co-operation amongst states."

2. See Grant Wardlaw, Political Terrorism (Canberra: Australian Institute of Criminology, 1986), 18.

3. Ibid., 23

4. See Adam Roberts "Apply the Law of War in Anti-Terror War Too." www.int. com/articles/34457.html, 1-6.

5. Phyllis Bennis. Lecture given on October 23, 2001: "The War and the International Arena: The UN and the Coalition." http://dc.indymedia.org/ audio ipsarchive.htm.

6. See also UN Security Council Resolutions 1368 (2001), 1373 (2001), and 1377 (2001).

7. Press Release 124, "Statement by the North Atlantic Council" (September 12, 2001), 40 ILM 1267 (2001), and NATO Website (September 29, 2001), www.nato.int.

8. NATO. Statement by former secretary general Lord Robertson (October 2, 2001). 40 ILM+. See also US: Public Law Joint Resolution to Authorise the 
Use of United States Armed Forces Against Those Responsible for the Recent Attacks Launched Against the United States. [Sept 18,2001] 40 ILM 1282 (2001)+.

9. Ian Traynor and Julian Borger, "Storm over Afghan Civilian Victims," The Guardian (12 February 2002): 1, 4-5.

10. Ibid., 1.

11. Ibid., 5 .

12. See Wardlaw, Political Terrorism, 103-30 on international and domestic attempts to deal with terrorism.

13. Noam Chomsky Interview, www.zmag.org/chomsky_interview_5.htm at p. 1 .

14. A. Obote-Odora "Defining International Terrorism," E Law, Murdoch University Electronic Journal of Law 6, no. 1 (March 1999). Available at file://D/ Temp/SWPM6794.htm.

15. See E. McWhinney "Aerial Piracy and International Terrorism: The Illegal Diversion of Aircraft and International Law," $2 d$ rev. ed. (Aspen: 1987), which gives comprehensive coverage on aerial terrorism; The Tokyo Convention of 1963 (Convention on Offences and Certain other Acts Committed on Board an Aircraft); The Hague Convention of 1970 (Convention for the Suppression of Unlawful Seizure of Aircraft); and the Montreal Convention of 1971 (Convention for the Suppression of Unlawful Acts against the Safety of Civil Aviation).

16. Chomsky, 4

17. Antonio Cassese "Ex iniuria ius oritur: Are we Moving towards International Legitimisation of Forcible Humanitarian Countermeasures in the World Community?" European Journal of International Law, UN. 10, no.1 (1999) at www.ejil.org/journal/Vol10/No1/com.htm1\#TopOfPagehtml.

18. See M. Lakehurst, "Jurisdiction in International Law," British Yearbook on International Law, no. 46 (1972-73): 145-257, for comprehensive coverage of executive, judicial, and legislative jurisdictional issues based on various principles of international law.

19. American Society of International Law Insights: Terrorist Attacks on World Trade Centre \& Pentagon. Professor Jordan J. Paust "War \& Response to Terrorism," Sept. 2001, 5.

20. See A. Cassese, "The International Community's Legal Response to Terrorism," International and Comparative Law Quarterly, no. 38 (1989): 598, where he states that coercive reprisal may be justified when the state is "connected" to the terrorist apparatus on six grounds.

21. See note 19, Professor Frederic L. Kirgis. September 2001, 2.

22. Ibid., John Cerone, Executive Director of the War Crimes Research Office at American University, Washington College of Law. "Acts of War \& State Responsibility in 'Muddy Waters': The Non-State Actor Dilemma," Sept. 2001, 6-9.

23. A. Cassese, "On the Current Trends towards Criminal Prosecution and Punishment of Breaches of International Humanitarian Law," European Journal of 
International Law (2000). Online at: www.ejil.org/journal/vol19/No1/art108.html.

24. See "Do Heads of State in Office Enjoy Immunity from Jurisdiction for International Crimes? The Ghaddafi Case Before the French Cour de Cassation: 5 Is Terrorism a Crime under International Customary Law, Entailing the Lifting of Heads of State's Immunity?" Online at www.ejil.org/journal/Vol112/No3/ art2-05.html, 1-5.

25. See "Bush fights rebels over tribunal." Online at http://news.bbc.co.uk/1/hi/ world/americas/5350270.stm.

26. See "Saddam had no link to al-Qaeda." Online at http://news.bbc.co.uk/1/hi/ world/americas/5328592.stm.

27. See "Terror Charges in Full: The Terror Charges Filed against the Alleged Plotters." Online at http://news.bbc.co.uk/1/hi/uk/5272264.stm.

28. Samuel P. Huntington, The Clash of Civilizations and the Remaking of World Order (United Kingdom: Simon \& Schuster, 1998); Noam Chomsky, World Orders, Old and New (London: Pluto Press, 1999).

29. Huntington, Clash of Civilizations, 35.

30. Ibid., 81 .

31. See "Rebuilding America's Defences: Strategy, Forces, and Resources for a New Century" (A Report of the Project for the New American Century September 2000). Online at www.newamericancentury.org/RebuildingAmericasDefenses.pdf

32. President Bush stated 'Imagine - imagine an enemy that can't stand what we believe in getting ahold of oil resources and taking a bunch of oil off the market in order to have an economic punishment. In other words, they say, you go ahead and do this, and if you don't, we'll punish you economically." Press Conference of the President, The Rose Garden (September 15, 2006). Online at www.whitehouse.gov/news/releases/2006/09/20060915-2.html.

33. Huntington, Clash of Civilizations. For a comprehensive coverage of transnational wars, see 246-98.

34. See Noam Chomsky, Frateful Triangle: The U.S., Israel, and the Palestinians, updated ed. (London: Pluto Press, 1999) for an account on the historical tensions in this region.

35. See Jeremy Carver and Jenine Hulsmann, "The Role of Article 50 in the UN Charter in the Search for International Peace and Security," International \& Comparative Law Quarterly, no. 49 (July 2000): 528-77; M. Jackson "Selective Intervention" (UN Presence in Israel), Middle East International, no. 667 (25 January 2002): 22-24.

36. See "Conflicts-Iran." online at www.bbc.co.uk/bbcthree/tv/conflicts/iran.shtml.

37. Huntington, Clash of Civilizations, 316.

38. See "Joint EU-U.S. Ministerial Statement on Combating Terrorism." [Sept 20, 2001] 40 International Legal Materials 1263 (2001) + www.eurunion.org"; European Union (EU): Conclusions Adopted By The Council (Justice \& 
Home Affairs) [Sept 20, 2001] 40 ILM 1257 (2001)+ www.euroinion.org; European Union (EU) Joint Declaration by the Head of State \& Government of the EU. The President of the European Parliament, The President of the European Commission, \& the Representative for the Common Foreign \& Security Policy [Sept 14, 2001] 40 ILM 1255 (2001)+ www.eurounion.org; European Union (EU): Conclusions \& Plans of Action of the Extraordinary European Council Meeting on 21 September 2001. 40 ILM 1264 (2001)+ www.eurounion.orgNorth American Treaty Organization (NATO): Statement by the North Atlantic Council [September 12 (2001)+ www.nato.int; Organisation of American States (OAS): Declaration of Solidarity from the House of the Americas [September 2001] 40 ILM 1269 (2001)+United States: Executive Order 13224 "Blocking Property \& Prohibiting Transactions with Persons Who Commit, Threaten to Commit, or Support Terrorism.” [Sept 25, 2001] 40 ILM 1283 (2001)+; United Nations Security Council Resolution 1373 on "Threats to International Peace \& Security Caused by Terrorist Acts. 2 [Sept 28 2001] 40 ILM 1278 (2001)+.

39 Timothy Shimeall, Phil Williams and Casey Dunlevy, "Countering Cyber War," NATO Review (winter 2001): 16-18.

40. Robert Hall and Carl Fox, "Rethinking Security," NATO Review (winter 2001): 8-11, and the interview with Ted Whitehead, head of NATO's Weapons of Mass Destruction Centre, NATO Review (winter 2001): 22-23.

41. Frank J. Cilluffo and Daniel Rankin, "Fighting Terrorism," NATO Review (winter 2001): 12-15. 